\title{
The Monetary Transmission Mechanism in Nigeria:
}

\section{A Sectoral Output Analysis}

\author{
Philip Ifeakachukwu, NWOSA (Correspondence author) \\ Department of Economics, Accounting and Finance \\ Bells University of Technology, Ota, Ogun State, Nigeria \\ Tel: 234-082-470-7555 E-mail: nwosaphilip@yahoo.com \\ Muibi Olufemi, SAIBU \\ Dept of Economics, Obafemi Awolowo University \\ Ile-Ife, Osun State, Nigeria \\ Tel: 234-085-338-1914Ｅ-mail: omosaibu@yahoo.com
}

Received: May 31, 2011

doi:10.5539/ijef.v4n1p204

\author{
Accepted: July 5, 2011 \\ Published: January 1, 2012 \\ URL: http://dx.doi.org/10.5539/ijef.v4n1p204
}

\begin{abstract}
The study investigated the transmission channels of monetary policy impulses on sectoral output growth in Nigeria for the period 1986 to 2009. Secondary quarterly data were used for the study while granger causality and Vector Auto-regressive Method of analysis were utilized. The results showed that interest rate channel was most effective in transmitting monetary policy to Agriculture and Manufacturing sectors while exchange rate channel was most effective for transmitting monetary policy to Building/Construction, Mining, Service and Wholesale/Retail sectors. The study concluded that interest rate and exchange rate policies were the most effective monetary policy measures in stimulating sectoral output growth in Nigeria.
\end{abstract}

Keywords: Sectoral output, Monetary transmission channels, Granger causality, VAR model

\section{Introduction}

The channels through which monetary policy impulse is being transmitted to the economy had been a subject of continuous discourse among academia's and researchers given that an understanding of the transmission of monetary policy to real output is key for central bankers to conduct monetary policy effectively. While issues on monetary transmission channels on aggregate output abound in the literature, a sectoral analysis of the transmission channels monetary policy impulse had suffered neglect. For a small open economy like Nigeria, it is also vital to analyze monetary policy transmission at the sectoral level for at least two reasons. First, there are mixed evidences regarding monetary policy transmission on individual sectors, and therefore it is worthwhile to update previous results via the utilization a wider range of econometric techniques. Two, an analysis of sectoral output would assist in the clarification of the policy transmission mechanism in different sectors of the economy and ultimately contribute to the understanding of the monetary policy mix to be adopted in order to ensure balanced growth in the economy.

Although plethora of similar studies exists in the literature, this study is distinct from previous attempts in several ways. First, it took a more comprehensive measure of real output from the sectoral point of view. Unlike earlier studies which examined either aggregate or one sector of the economy and used only one or two measures of monetary policy, this study analysed the monetary transmission channels in six sectors of the economy. Apart from this sectoral disaggregation, it also used three different measures of monetary policy as independent variables (interest rate, credit to private sector and exchange rate). In addition, hardly have any of the existing studies (such as Ogun, 2006; Oyaromade, 2002) in Nigeria examined more than one channel of policy transmission, much of existing studies identified all the channels but concentrated only on the credit channel. The neglect of the other channels without any empirical justification raise doubt about the policy inferences from their studies as there could be more than one channel of influence as suggested by theories and evidence from studies on other economies (King, 1994). 
The rest of the paper is structured as follows. In addition to the introduction, section two presented the literature review while section three discussed the methodology on which this study is based. Section four presented the analysis of empirical results while section five contains summary and policy implications.

\section{Literature Review}

One of the first notable attempts to explore monetary transmission at the disaggregated level was the study by Bernanke and Gertler (1995). Utilizing a vector autoregressive (VAR) model, the study revealed that monetary policy impacted differently on different components of final expenditures. Since then plethora studies have emerged analyzing the impact of monetary policy on different sectors or regions of the economy in more detail. For instance, Raddatz and Rigobon (2003) find supportive evidence on differential effects of monetary policy for various sectors of the US economy. Similar study in the US by Gertler and Gilchrist (1993) found that outputs of the smaller firms were more sensitive to monetary shocks as compared to large sized firms. Disaggregating the Canadian economy at the level of final expenditures as well as at the level of output, Farès and Srour (2001) collect evidence of differing response of various sectors of the economy to innovations in monetary policy. Analyzing the UK data, Tena and Tremayne (2006) collect evidence of cross-sectional differences across industries and asymmetries in some sectors to a monetary policy change while Ganley and Salmon (1997) provide evidence that the construction sector is the most interest-sensitive sector, followed by the manufacturing industry, services, and agriculture.

Hayo and Uhlenbrock (1999) focused on the Germany's manufacturing and mining sector, and concluded that heavy industries respond more strongly to interest rate shocks than the production of nondurables industries such as clothing and food. Using disaggregated industry data from five industrialized countries, Dedola and Lippi (2005) revealed that sizable and significant cross-industry differences in the effects of monetary policy. From a panel of US regional data Giacinto (2002), Fratantoni, Schuh and Mae (2001) and Carlino and DeFina (1999) estimate differential effects of monetary policy shocks. The analyses from these studies showed a significant variation in the magnitude and duration of dynamic responses to monetary shocks across regions of the USA. Carlino and DeFina (1999) further employed the estimated states impulse responses in a cross-state regression model to determine the causes of these state responses. The result showed that a state's response to monetary policy is positively related to its manufacturing share and negatively related to the percentage of small banks. The study therefore concluded that the existence of disparate in states responses, underscores the difficulty of conducting a national monetary policy. Cortes and Kong (2007) also examined the impact of monetary policy on the different province of the Chinese economy. The findings of the study indicated that bank-lending rate is a better indicator of monetary policy in China. The study further revealed that the coastal provinces responded more to shock in monetary policy than the inland provinces; and established that differential provincial responses to monetary policy changes were positively related to the share of loans accounted for by the industrial firms and the primary sector of the country's aggregate output. In addition, the percentage of firms that are state-owned (a proxy for the soft budget constraint) has a negative, albeit statistically insignificant relationship to a province's response to monetary policy shocks. Also, Yue and Shuang-hong (2007) examined monetary policy transmission through the interest rate channel in China using the granger causality test and found that there was no causality between investment expenditure and the market interest nor between household consumption and the market interest rate, which suggested that the transmission of monetary policy in China was uncertain.

In Netherlands Arnold and Vrugt (2002) measure the impact of monetary policy shocks on regional and sectoral output and the study observed large regional and sectoral variation in monetary policy transmission. Alam, and Waheed (2006) examine channels of monetary transmission in Pakistan across seven sectors (agriculture, mining and quarrying, manufacturing, construction, wholesale and retail trade, finance and insurance, and ownership of dwellings) of the economy; the finding of the study revealed that the manufacturing, wholesale and retail trade, and finance and insurance sectors declined more in response to the interest rate shocks while the agriculture, mining and quarrying, construction, and ownership of dwellings were observed to be insensitive to interest rate changes.

With respect to the Nigerian economy, past research on monetary transmission mechanism (see Oyaromade, 2002; Uchendu, 1997; Adebiyi, 2006; Ogun, 2006) has focused on the response of aggregate variables to monetary shocks. This paper takes a first step in investigating the monetary transmission mechanism in Nigeria at a sectoral level.

\subsection{Theoretical Framework}

Drawing from the various theories on the channels of monetary transmission (see Mishkin, 2004), this study adopted the Keynesian prescriptions as the framework for analyzing the transmission channels of monetary policy to real sectoral outputs. In the Keynesian approach, a discretionary change in monetary policy affected the real economy through the two sides of market forces- the demand and supply sides. From the aggregate demand side, monetary policy was transmitted either directly through three channels; the exchange rate, the interest rate and wealth channel 
or indirectly through the bank credit which was transmitted through two channels: the bank-lending channel and the balance sheet channel. From the supply side, monetary policy impulse affected real variables via changes in inventory cost (Baksh and Craitgwell, 1997).

While acknowledging the supply side channel, this study adopted aggregate demand side channels. For two reasons; first, in Keynesian framework, the aggregate supply was relatively fixed due to stickiness of price at least in the short run. Second, the Nigerian economy is structurally weak and not well developed to allow the necessary adjustment to take place if the inventory cost approach is to be relevant. The economic intuition behind the aggregate demand channels of policy influence on real variables is usually described by the traditional Keynesian (IS-LM) framework. The framework focused on the equilibrium position between the demand for and the supply of money to determine the rate of interest, which influenced investment spending and consequently output level (Dornbusch et al, 2002). It dichotomized the economy into real and money sector. The IS curve represented equilibrium in the real sector while the LM curve represented equilibrium in the money market. The theoretical linkage was represented in the diagram below.

Insert Figure 1 Here

An important observation with the theoretical exposition above is that interest rate is cardinal in any channel monetary policy passes through to the real sector. So in recognising this fact, the channel that formed the basis for the subsequent analysis was represented schematically as:

$$
\mathbf{M}_{\mathbf{s}} \uparrow \rightarrow \mathbf{i} \downarrow \rightarrow \mathbf{P S C} \uparrow \rightarrow \mathbf{P}_{\mathbf{s}} \uparrow \rightarrow \mathbf{E}_{\mathbf{r}} \downarrow \rightarrow \mathbf{I} \uparrow \rightarrow \mathbf{Y} \uparrow
$$

$\mathrm{M}_{\mathrm{s}} \uparrow$ indicates expansionary monetary policy resulting from government purchases of securities in the open market, leading to a fall in real interest rate, which in turn: (a) increases the amount of credit by banks to the private sector; (b) increases in the price of security prices given the inverse relationship between security prices and interest rate and (c) decreases in exchange rate; these effects stimulate investment and consequently output.

\section{Research Methodology}

The empirical approach utilized in this study is the unrestricted vector auto-regression model. This method represents standard practice in assessing the dynamic responses of real output to monetary policy shocks. Six VAR systems, for the six sectors of the Nigerian economy were estimated. Each system consists of five endogenous variables: monetary policy variables (interest rate, exchange rate and credit to private sector), asset price and consumer price index; (Note 1) and one exogenous variable, sectoral output as specified in equation one below. Our model follows that of earlier studies with the main difference that, it also estimated the granger causality test in line with the study by Yue and Shuang-hong (2007). Quarterly data spanning from 1986:1 to 2009:4, were used and the sectors included are agriculture (agric), mining (min), manufacturing (man), construction and construction (bcn), wholesale and retail trade (wrt) and the service (ser) sector. All variables except for the interest rate and exchange

rate are expressed in logarithmic form. The unrestricted VAR model for this study is specified as follows:

$$
X_{t}=\alpha+B_{1} X_{t-1}+B_{2} X_{t-2}+B_{3} X_{t-3}+\ldots \ldots+B_{q} X_{t-k}+u_{t}
$$

\section{Where: $\quad X_{t}=\left[\begin{array}{llllll}Y^{t} & I N T & E X T & L P S C & L C P I & L A S P\end{array}\right]^{1}$}

$X_{t}$ is a $k x 1$ - dimensional Vector of the endogenous variables, $\alpha$ is a $k x l$ - dimensional vector of constant and $\mathrm{B}_{1 \ldots \ldots \ldots . . . .} \mathrm{B}_{\mathrm{q}}$ are $k x k$ dimensional autoregressive coefficient matrices and $\mu$ is $k$-dimensional vector of the stochastic error term nominally distributed with white noise properties $\mathrm{N}\left(0, \sigma^{2}\right)$.

Given equation (1) above, the estimating variables entered the unrestricted VAR model in the following sequence; the exchange rates (EXT); the interest rate (INT); domestic credit (LPSC); asset price index (LASP); the consumer price index $(L C P I)$ and the sectoral outputs $\left(Y^{i}\right)$. The ordering of the variables is based on the assumption that interest rate (a proxy for monetary policy stance) reacts to changes in exchange rates but did not respond to contemporaneous changes in other variables within the VAR model while the real sector output is expected to react to changes in other macroeconomic variables in the model. Furthermore, a common lag length of three for each VAR sectoral model was adopted for the models. The choice of this lag length has the advantage of whitening the errors for each of the individual VAR. This is in line with other similar studies in the literature. Dungey and Pagan (2000), Berkelmans (2005) and Crawford (2007) argued that a lag selection of three was capable of generating a smoother and more reasonable VAR estimate especially with quarterly data series on macroeconomic variables. 


\section{Estimating Result}

This study commenced it empirical analysis by conducting the granger causality test following study by Yue and Shuang-hong (2007). The granger causality approach was employed to examine the one-to-one possible link between sectors' output and monetary variables. The outcome of this granger causality test was used to detect the possible channel of policy transmission between the monetary variables and the sectors of the Nigerian economy. The granger causality result is presented on Table 1 below. Study by Yue and Shuang-hong (2007) utilized this method to determine the channel of transmitting monetary policy impulses to the real sector.

The results of the granger causality test showed that agriculture, service and wholesale and retail sector were affected by bank credit, asset price and inflation rate implying that monetary policy impulses were capable of being transmitted to these sectors through the credit and asset price channels of monetary transmission mechanism. The mining sector and the building and construction sector were influenced by changes in exchange rate, bank credit, and asset price and inflation rate.

In similar manner, the credit and asset price channels were potential channels through which monetary policy impulses were transmitted to these sectors. Manufacturing output was also influenced by all the variables suggesting that all channels are potential conduit through which monetary policy impulse was transmitted to the manufacturing sector. With respect to other variables in the model, Table 1 showed that inflation rate granger caused exchange rate while asset price granger caused bank credit.

An important observation from Table 1 below was the distinction in some policy variables influencing the different sectors; suggesting the potentiality of the different channels in transmitting monetary policy impulse to the real sector. In addition, the result showed that the relative importance of the various channels in transmitting monetary policy impulse via the different channels to the sectors differed.

Given the different significant levels at which each variable granger caused real output of the different sectors; it difficult to isolate the most relevant channel through which monetary policy is transmitted to each sector. Therefore, to establish the specific channel of monetary transmission mechanism with respect to each sector, the variance decomposition was used to determine the most significant channels in each sector of the economy. In line with Oyaromade (2002) and Era-Dabla and Holger (2006), the monetary policy variable which accounted for the largest proportion of the variation in each sectoral output model, was taken as the most significant channel through which monetary policy was transmitted to real sector in this study.

In addition to the granger causality estimate, Table 2 below presents the variance decomposition estimates generated from the unrestricted VAR models for forecast horizon 1, 4, 8 and 12 quarters. As evident on Table 2 shocks to interest rate explained the largest variation in agricultural output. Although shock to interest rate counted for less than 1.0 per cent of changes in agricultural output growth in the first quarter, it however increased to 7.0 percent by the fourth quarter and further to 9.0 per cent in the eight quarter and twelfth quarters respectively. The contribution of exchange rate to changes in agricultural output growth was about 3.0 per cent in the first quarter before declining progressively to about two per cent in the twelfth quarter. Also shock to bank credit contributed about 2.0 per cent in the second quarter before declining marginally to 1.9 per cent in the twelfth quarter while the contributions of shocks to asset price and consumer price index were less than 2.0 per cent over the twelve-quarter period. This implied that the interest rate as a monetary policy instruments has a stronger effect on the agricultural sector than other policy variables. This result supported the hypothesis that the interest rate channel plays a significant role in transmitting monetary policy impulse to the agricultural sector. The agricultural sector constitute the largest sector in terms of output contribution to aggregate output, therefore changes in the sector's output is expected to have large impact on aggregate output.

Shocks to exchange rate accounted for the most source of variation in building and construction. It explained about 5.0 per cent of changes in building and construction output growth in the first quarter, increasing to about 6.0 percent by the fourth quarter before declining marginally to about 5.0 per cent in the eight quarter and twelfth quarters respectively. The contribution of shocks to interest rate to building and construction output growth rose marginally from about 1.0 per cent in the second quarter to about 2.0 per cent in the twelfth quarter. Also the contributions of shocks to bank credit and asset price were on average less than 2.0 per cent over the twelve-quarter period. The significance of the exchange rate on the building and construction sector was also evident from the correlation and granger causality result. Thus, suggesting that the exchange rate as a monetary policy instruments has a stronger effect on the building \& construction sector than other policy variables. A possible explanation to the strong influence of the exchange rate channel on the building and construction sector could reflect the sensitivity of the sector to foreign inputs used in this sector, thus variations in exchange rate significantly impact on this sector. This result confirmed the findings by Granley and Salmon (1997). 
With respect to the manufacturing sector, shocks to interest rate had the largest influence on the sector's output. As observed from Table 2, shock to interest rate rose significantly from less than 1.0 per cent in the first quarter to about 8.0 per cent in the twelfth quarter while shocks to exchange rate and asset price declined steadily from 4.8 and 4.3 per cent in the first quarter to 2.5 and 2.3 per cent in twelfth quarter respectively. This finding supported the granger causality result of the significance of interest rate among other variables in affecting the manufacturing sector thus suggesting the prominence of the interest rate channel among other channels of transmission mechanism in transmitting monetary policy impulses to the manufacturing sector. This finding was consistent with the study of Ganley and Salmon (1997), Hayo and Uhlenblock (1999) and Crawford (2007). The sensitivity of the interest rate channel to the manufacturing sector could reflect the extent of capital intensity within the sector. The manufacturing sector might be connected to the exchange rate channel given the reliance of this sector on foreign inputs whose prices are determined mostly by variations in exchange rate. In addition, it might be connected to Tobin's q channel because most of the dominant manufacturing firms are quoted on the stock market and variations in asset prices of this firm would to some extent might have influenced productivity within the firms in particular and the sector in general.

For the mining sector, shock to exchange rate contributed the largest source of changes in the sectors output growth among the monetary policy variables. Exchange rate contributed about 7.0 per cent in the first quarter before declining marginally to about 6.0 per cent in the twelfth quarter. Also shocks to interest rate on the mining sector experienced a gradual increase from about less than 1.0 per cent in the first quarter to about 4.0 per cent in the eighth and twelfth quarter while the average contribution of shocks to bank credit and asset price were below 1.0 per cent over the twelfth-quarter period. This finding confirmed the correlation and the granger causality result and consequently established that the exchange rate channel played a significant role in transmitting monetary policy impulse to the mining sector. This finding is consistent with the study of Hayo and Ublenblock (1999).

Furthermore, Table 2 established that shocks to exchange rate experienced a progressive contribution to the service sector from 2.5 to 3.7 and further to 3.9 per cent in the first, fourth and twelfth quarters respectively. In addition, shock to asset price experienced a progressive contribution to the service sector from 2.6 to 3.8 in the first and second quarter before declining marginally to 3.3 per cent in the twelfth quarter. Shock to interest rate and bank credit to wholesale and retail sector were less than one per cent on average over the twelfth quarter period. An important finding here is that the exchange rate channel and the Tobin's q channel plays a significant role in transmitting monetary policy impulse to the mining sector while other monetary transmission channels are irrelevant to the service sector.

Shock to exchange rate contributed the largest source of variations in the wholesale and retail sector. It is evident from Table 2 below that exchange rate contributed about eight per cent in the first quarter and increased marginally to about nine per cent in the twelfth quarter. Also shocks to interest rate on the wholesale and retail sector experienced a slow-steady increase from about less than one per cent in the first quarter to about five per cent in the twelfth quarter while the average contribution of shocks to bank credit and asset price were below one per cent over the twelfth-quarter period. An important observation here is that the exchange rate channel plays a significant role in transmitting monetary policy impulse to the wholesale and retail sector while other monetary transmission channels are irrelevant to the mining sector. An important explanation to the sensitivity of the exchange rate channel to the wholesale and retail sector is that the wholesale and retail sector is mostly engaged in the on-selling of manufactured product, most of which are imported. Thus variations in exchange rate affect the activities within this sector.

The above analysis on the channels through which monetary policies were transmitted to specific sector revealed that: Firstly, there some differences between the channels through which monetary policy was transmitted to some sectors of the Nigerian economy. Secondly, only two channels of monetary transmission were outstanding with respect to the different sectors. The interest rate channel was responsible to transmitting monetary policy to the agriculture and manufacturing sector. The exchange rate channel was responsible for transmitting monetary policy impulse to the building and construction, mining, service and wholesale and service sector and thirdly the result further revealed that the credit channel and asset price channel are weak channels of transmitting monetary policy impulse to the different sectors of the Nigeria economy.

The findings from the above empirical estimates thus confirmed the reservation about the results and methodological approach adopted by earlier studies in their analyses of transmission mechanism in Nigeria. One, there were significant differences in the channels of influence of monetary policy between sectoral output variables. Therefore, the implicit assumption of homogeneity in policy recommendation across different sectors, due to their failure to explore the sectoral output analysis might have significant impaired the policy relevance of their outcomes (Ogun, 2006; Oyaromade, 2002, 2006; Adebiyi 2006). Two, the exploration of several other channels by this study also revealed that exchange rate channel, which had been ignored in the past studies, was relevant in monetary 
policy transmission in Nigeria with respect to the mining and manufacturing sector. This, therefore suggest that policy recommendation should be sector specific and a-one- fit all policy was not feasible for different sectors of Nigerian economy.

An important observation with this result in the light of the theoretical transmission mechanism depicted as $\mathbf{M}_{\mathbf{s}} \uparrow \rightarrow \mathbf{i} \downarrow \rightarrow \mathbf{P S C} \uparrow \rightarrow \mathbf{P}_{\mathbf{s}} \uparrow \rightarrow \mathbf{E}_{\mathbf{r}} \downarrow \rightarrow \mathbf{I} \uparrow \rightarrow \mathbf{Y} \uparrow$ (in section 2.1) was that the finding in this study confirmed the adequacy and comprehensiveness of the framework to capture the nexus between monetary policy and real economic growth in Nigeria. However, the evidence provided in this study did not support the central role played by asset price in monetary policy transmission. Therefore, asset price might not be a relevant conduit of monetary policy innovation and hence removing it from the framework might not disconnect the real sector from the monetary sector. Similarly, bank credit is also of little relevance. Therefore, if at all, bank credit play any significantly role as posited by studies (Oyaromade, 2006) which used aggregate data, such role must be indirect. So the basic transmission mechanism detected by data in this study is depicted as follows;

$$
\mathbf{M s} \uparrow \rightarrow \mathbf{i} \downarrow \rightarrow \mathbf{E}_{\mathbf{r} \downarrow} \rightarrow \mathbf{I} \uparrow \rightarrow \mathbf{Y} \uparrow
$$

That is, an expansionary monetary policy leads to fall interest rate and this fall in interest rate lead to depreciation in exchange rate (i.e. a fall in value of naira relative to other currency). The combined effect of fall in interest rate and fall in the value of domestic currency will boost investment, which subsequently boost output growth in the economy.

\section{Conclusion and Policy Recommendation}

This study examined the channels of monetary transmission mechanism across the different sectors of the Nigerian economy. To achieve the objective of study both granger causality and vector error correction methodology were used and the findings of study revealed that the channels through which monetary policies were transmitted to specific sector were different. Only two channels of monetary transmission were outstanding with respect to the different sectors. The interest rate channel was responsible for transmitting monetary policy impulse to the agriculture and manufacturing sectors while the exchange rate channel was the most pronounced channel for transmitting monetary policy impulse to the building and construction, mining, service and wholesale and service sectors. According to Lopes (1998), the ineffectiveness of the asset and credit channel can be attributed to the presence of high inflation in the economy. During the period of high inflation the monetary authority cannot easily control the direction of interest rate as a result of the existence of high volatility premium in agent's expectations. More so, Lopes argued that the inefficiency in the asset and credit channel under high inflation could also be ascribed to the absence of long-term debt instruments; and that these instruments are important because the longer the life cycle of the instrument the greater the impact of interest rate changes on the value of the instrument. Finally the ineffectiveness of the asset and credit channel can also be ascribed to the poorly developed nature of the financial market which has greatly impeded the effectiveness of monetary policy on the real sector.

The study concluded that the existence of disparity in the transmission channels of monetary policy impulse to different sectors of the Nigerian economy, underscored the difficulty in conducting a uniform and economic wide monetary policy in Nigeria. Therefore, the best policy approach to adopt is a sector specific policy, based on their relative strength and significance of each sector of the economy within the overall monetary policy mechanism framework. To stimulate output in the agriculture and manufacturing sector the interest rate channel should be emphasized while to stimulate output growth in the building and construction, mining, service and wholesale and service sector focus might be placed on the exchange rate channel. This also requires judicious management of exchange rate policy to promote growth within these sectors.

Finally, improving monetary policy efficiency on sectors' output will require further regulatory reforms and the strengthening of monetary policy implementation. Several measures could be implemented in the short term to strengthen the exchange rate channel and interest rate channel. Monetary transmission through the credit channel can be strengthened by tightening creditworthiness standards; strengthening accounting standards, bankruptcy laws, corporate governance, and creditor rights; improving bank credit assessment capabilities; and strengthening the judicial system to improve banks' ability to enforce on collateral (Era-Dabla and Holger, 2006). In addition to ensuring the effectiveness of the asset price and credit channels, the monetary authority should maintain a low and stable inflationary level.

\section{References}

Adebiyi, M. A (2006). Financial Sector Reforms and the Transmission Mechanism of Monetary Policy in Nigeria. A Vector Auto-regression Mechanism, China Finance Research Network (CFRN). 
Alam, T., \& Waheed, M. (2006). The Monetary Transmission in Pakistan. A Sectoral Analysis: Pakistan Institute of Development Economics. Munich Personal RePEc Archive (MPRA) No. 2719.

Arnold, I. J. M., \& Vrugt, E. B. (2002). Regional Effects of Monetary Policy in the Netherlands. International Journal of Business and Economics, 1, pp. 123-34.

Baksh, S., \& Craigwell, R. C. (1997). The Monetary Transmission Mechanism in a Small Open Economy. A Case of Barbados. Savings and Development, Vol. 21 (2) pp 179-193.

Berkelmans, L. (2005). Credit and Monetary Policy. An Australian SVAR. Reserve Bank of Australian Research Discussion Paper 2005-06; 2005 (September), 1-29.

Bernanke, B., \& Gertler, M. (1995). Inside The Black Box: The Credit Channel of Monetary Transmission. Journal of Economic Perspectives, Vol. 9 No.4 pp 27-48. http://dx.doi.org/10.1257/jep.9.4.27.

Carlino, G., \& Defina, R. (1999). The Differential Regional Effects of Monetary Policy: Evidence from the USA. Journal of regional science, Vol. 39 (2) pp 339-358. http://dx.doi.org/10.1111/1467-9787.00137

Cortes, B. S., \& Kong, D. (2007). Regional Effect of the Chinese Monetary Policy. The International Journal of Economics Policy Studies. Article 2, Volume 2 pp 15 -28.

Crawford, C. (2007). The Sectoral Impact of Monetary Policy in Australia, A structural VAR Approach.

Dedola, L., \& Lippi, F. (2005). The Monetary Transmission Mechanism: Evidence from the industries of five OECD countries, European Economic Review, 49, pp. 1543-1569. http://dx.doi.org/10.1016/j.euroecorev.2003.11.006

Dornbusch R., Fischer, S. \& Richard, S. (2002). Macroeconomic, Eighth Edition. Tata Mc Graw-Hill Companies Inc. ISBN 0-07-047434-6.

Dungey, M., \& Pagan, A. (2000). A Structural VAR of the Austrian Economy. Economic Record, Vol. 76 (235) pp 321-342. http://dx.doi.org/10.1111/j.1475-4932.2000.tb00030.x

Era-Dabla, N. \& Holger, F. (2006). Transmission Mechanism of Monetary Policy in America: Evidence from VAR Analysis. IMF Working Paper Middle East and Central Asia Department) WP/06/248.

Farès, J., \& Srour, G. (2001). The Monetary Transmission Mechanism at the Sectoral Level,' Bank of Canada Working paper 2001-27.

Fratantoni, M., Schuh, S., \& Mae, F. (2001). Monetary Policy, Housing and Heterogeneous Regional Markets, Federal Reserve Bank of Boston, Working paper.

Gertler, M., \& Gilchrist, S. (1993). The Role of Credit Market Imperfection in the Monetary Transmission: Arguments and Evidence. Scandinarian Journal of Economic, Vol. 95 (1) pp 43-64. http://dx.doi.org/10.2307/3440134

Giacinto, V. Di. (2002). Differential Regional Effects of Monetary Policy: A Geographical SVAR Approach, European Regional Science Association conference paper 02-257.

Granley, J., \& Salmon, C. (1997). The Industry Impact of Monetary Policy Shock. Some Stylised Facts. Working paper No. 68. Bank of England.

Hayo, B. \& Uhlenbrock, B. (1999). The Industry Effect of Monetary in Germany. Center for European Integration Studies. (ZEI)Working Paper B14.

King, M. (1994). The Transmission Mechanism of Monetary Policy. Bank of England Quarterly Bulletin, pp. 261-267.

Lopes, F. (1998). The Transmission Mechanism Of Monetary Policy In A Stabilization Economy: Note on the Case of Brazil, Bank of International Settlement Policy Papers, No.3 pp. 65-73.

Mishkin, F. S. (2004). The Economic of Money, Banking and Financial Market. Seventh Edition. Columbia University. The Addison Wesley Series in Economics.

Ogun, T. P. (2006). Financial Structure, Bank Credit Channel and Monetary Policy In Nigeria (1970-2003). Unpublished P.hD Thesis. Department of Economics, Faculty of Social Sciences, Obafemi Awolowo University, Ile-ife, Osun -State.

Oyaromade, R. (2002). Monetary Policy Transmission in Nigeria. A VECM Approach. The Nigeria Journal of Economic and Social studies, Volume 44, pp. 187-206. 
Oyaromade, R. (2006). Monetary Policy Transmission, Credit Availability Doctrine and Credit Rationing Hypothesis: A Literature survey. Applied Macroeconomics and Economic Development, Ibadan University Press. pp 217-251.

Raddatz, C., \& Rigobon, R. (2003). Monetary Policy and Sectoral Shocks: Did the Federal Reserve React Properly to the High-Tech Crisis. Policy Research Working Paper Series, 3160. The World Bank.

Uchendu, O. A. (1997). The Transmission Mechanism of Monetary Policy in Nigeria, Central Bank of Nigeria. Economic and Financial Review, Vol.34, No.2 pp 606-625.

Yue, Yiding, \& Zhou, Shuanglong. (2007). Empirical Analysis of Monetary Policy Transmission through Interest Rate Channel in China. China Business Review, 1SSN 1537-1506, USA, Vol.6, No.3 serial No: 451 pp 8 - 13.

\section{Notes}

Note 1. The consumer price index is included in the VAR model to help prevent "puzzle"-in results which has been indentified inconsistent with conventional theory or empirical observations and the all share price index(ASP) captures the Tobin's q channel of monetary transmission mechanism

Table 1. Granger Causality between Real Output and Monetary Policy Variables

\begin{tabular}{|c|c|c|}
\hline $\mathbf{H}_{0}$ & F-Stat/Prob Value & Conclusion \\
\hline LPSC $\rightarrow$ LAGRIC & $8.3375(0.0004)^{*}$ & Unidirectional Causality From LPSC $\rightarrow$ LAGRIC \\
\hline LASP $\rightarrow$ LAGRIC & $5.4028(0.0062)^{*}$ & Unidirectional Causality From LASP $\rightarrow$ LAGRIC \\
\hline LCPI $\rightarrow$ LAGRIC & $5.4776(0.0058)^{* *}$ & Unidirectional Causality From LCPI $\rightarrow$ LAGRIC \\
\hline LEXT $\rightarrow$ LMIN & $9.2627(0.0002)^{*}$ & Unidirectional Causality From LEXT $\rightarrow$ LMIN \\
\hline LPSC $\rightarrow$ LMIN & $10.8378(0.0000)^{*}$ & Unidirectional Causality From LPSC $\rightarrow$ LMIN \\
\hline $\mathbf{L A S P} \rightarrow \mathbf{L M I N}$ & $13.7100(0.0000)^{*}$ & Unidirectional Causality From LASP $\rightarrow$ LMIN \\
\hline $\mathrm{LCPI} \rightarrow \mathrm{LMIN}$ & $18.0417(0.0000)^{*}$ & Unidirectional Causality From LCPI $\rightarrow$ LMIN \\
\hline LINT $\rightarrow$ LMAN & $4.7757(0.0108)^{* *}$ & Unidirectional Causality From LTBR $\rightarrow$ LMAN \\
\hline LEXT $\rightarrow$ LMAN & $3.4753(0.0354)^{* *}$ & Unidirectional Causality From LEXT $\rightarrow$ LMAN \\
\hline LPSC $\rightarrow$ LMAN & $6.3970(0.0026)^{* *}$ & Unidirectional Causality From LPSC $\rightarrow$ LMAN \\
\hline LASP $\rightarrow$ LMAN & $5.8269(0.0043)^{* *}$ & Unidirectional Causality From LASP $\rightarrow$ LMAN \\
\hline $\mathrm{LCPI} \rightarrow \mathrm{LMAN}$ & $4.4319(0.0148)^{* *}$ & Unidirectional Causality From LCPI $\rightarrow$ LMAN \\
\hline LEXT $\rightarrow$ LBCN & $8.0565(0.0006)^{*}$ & Unidirectional Causality From LEXT $\rightarrow$ LBCN \\
\hline $\mathbf{L P S C} \rightarrow \mathbf{L B C N}$ & $66.0356(0.0000)^{*}$ & Unidirectional Causality From LPSC $\rightarrow$ LBCN \\
\hline $\mathbf{L A S P} \rightarrow \mathbf{L B C N}$ & $35.6176(0.0000)^{*}$ & Unidirectional Causality From LASP $\rightarrow$ LBCN \\
\hline $\mathrm{LCPI} \rightarrow \mathrm{LBCN}$ & $32.5604(0.0000)^{*}$ & Unidirectional Causality From LCPI $\rightarrow$ LBCN \\
\hline LPSC $\rightarrow$ LWRT & $4.5063(0.0138)^{* *}$ & Unidirectional Causality From LPSC $\rightarrow$ LWRT \\
\hline $\mathbf{L A S P} \rightarrow$ LWRT & $3.3361(0.0403)^{* *}$ & Unidirectional Causality From LASP $\rightarrow$ LWRT \\
\hline LCPI $\rightarrow$ LWRT & $9.3178(0.0002)^{*}$ & Unidirectional Causality From LCPI $\rightarrow$ LWRT \\
\hline LPSC $\rightarrow$ LSER & $8.8827(0.0003)^{*}$ & Unidirectional Causality From LPSC $\rightarrow$ LSER \\
\hline LASP $\rightarrow$ LSER & $6.0332(0.0036)^{* *}$ & Unidirectional Causality From LASP $\rightarrow$ LSER \\
\hline LCPI $\rightarrow$ LSER & $10.7421(0.0000)^{*}$ & Unidirectional Causality From LCPI $\rightarrow$ LSER \\
\hline $\mathrm{LCPI} \rightarrow \mathrm{LEXT}$ & $4.1329(0.0194)^{*}$ & Unidirectional Causality From LCPI $\rightarrow$ LEXT \\
\hline $\mathbf{L A S P} \rightarrow \mathbf{L P S C}$ & $3.9661(0.0226)^{*}$ & Unidirectional Causality From LASP $\rightarrow$ LPSC \\
\hline
\end{tabular}

*/** Significant at $1 / 5$ percent level 


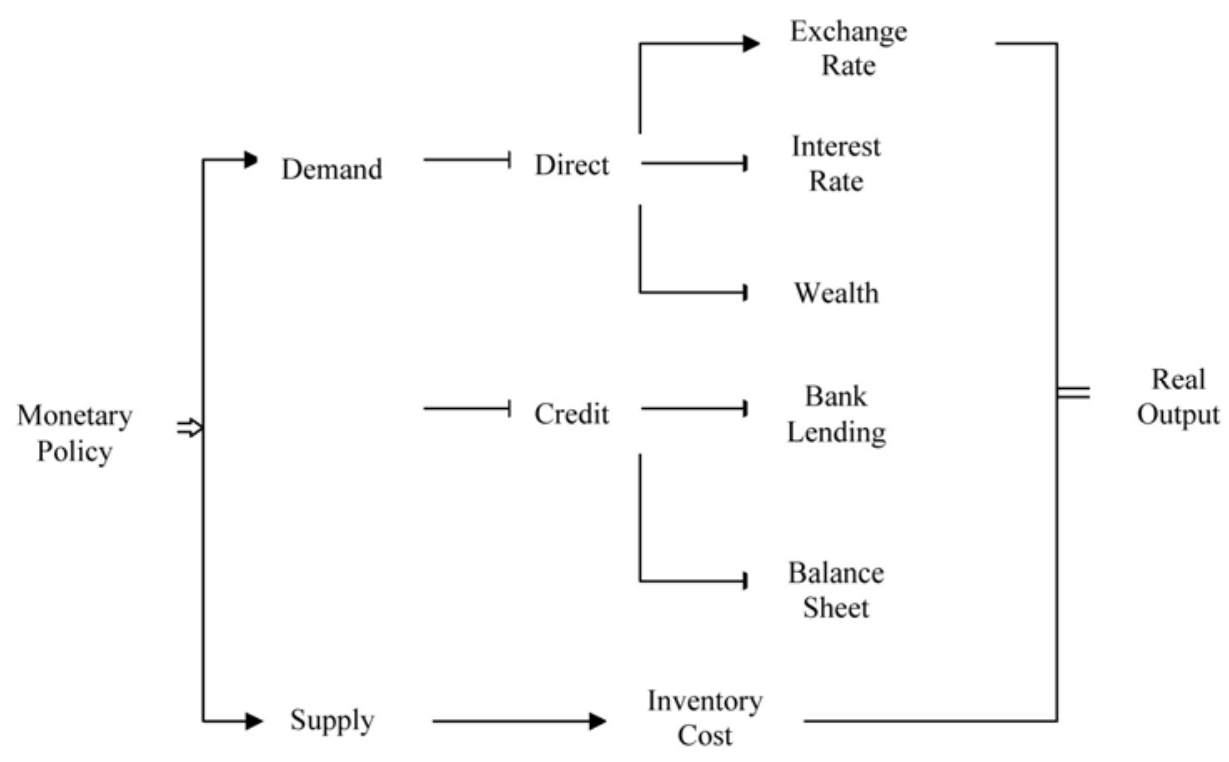

Source: Baksh and Craitgwell (1997) as adapted by Oyaromade (2006)

Figure 1. Theoretical Framework of the Monetary transmission Mechanism

\begin{tabular}{|lccccccc|}
\hline & forecast & ext & int & psc & asp & cpi & S.E \\
\hline agric & 1 & 3.430 & $\mathbf{0 . 4 9 3}$ & 0.785 & 0.901 & 1.027 & 0.140 \\
& 4 & 2.430 & $\mathbf{7 . 0 2 8}$ & 2.167 & 1.241 & 0.914 & 0.149 \\
& 8 & 1.970 & $\mathbf{8 . 7 1 0}$ & 2.007 & 1.041 & 0.891 & 0.150 \\
& 12 & 1.829 & $\mathbf{9 . 3 3 4}$ & 1.930 & 0.995 & 0.888 & 0.150 \\
\hline ben & 1 & $\mathbf{5 . 2 9 1}$ & 0.000 & 0.888 & 0.084 & 3.317 & 0.137 \\
& 4 & $\mathbf{5 . 8 7 5}$ & 1.088 & 1.163 & 1.117 & 9.989 & 0.145 \\
& 8 & $\mathbf{5 . 2 2 9}$ & 1.962 & 0.969 & 1.168 & 10.339 & 0.147 \\
& 12 & $\mathbf{5 . 0 6 4}$ & 2.334 & 0.885 & 1.183 & 10.473 & 0.148 \\
\hline man & 1 & 4.769 & $\mathbf{0 . 1 1 8}$ & 1.702 & 4.332 & 7.974 & 0.138 \\
& 4 & 2.600 & $\mathbf{7 . 6 7 3}$ & 1.739 & 2.455 & 8.718 & 0.149 \\
& 8 & 2.530 & $\mathbf{7 . 7 4 0}$ & 1.657 & 2.325 & 8.109 & 0.150 \\
& 12 & 2.531 & $\mathbf{7 . 7 5 7}$ & 1.645 & 2.313 & 8.041 & 0.150 \\
\hline min & 1 & $\mathbf{7 . 1 9 2}$ & 0.045 & 0.126 & 0.266 & 4.336 & 0.140 \\
& 4 & $\mathbf{5 . 9 1 8}$ & 3.586 & 1.047 & 0.401 & 11.429 & 0.149 \\
& 8 & $\mathbf{5 . 9 6 1}$ & 3.912 & 1.075 & 0.421 & 11.484 & 0.150 \\
& 12 & $\mathbf{5 . 9 6 2}$ & 3.919 & 1.077 & 0.421 & 11.485 & 0.150 \\
\hline ser & 1 & $\mathbf{2 . 4 8 5}$ & 0.295 & 0.138 & $\mathbf{2 . 5 5 9}$ & 2.182 & 0.137 \\
& 4 & $\mathbf{3 . 7 5 1}$ & 0.213 & 0.463 & $\mathbf{3 . 7 9 9}$ & 7.327 & 0.146 \\
& $\mathbf{3 . 9 1 4}$ & 0.166 & 0.364 & $\mathbf{3 . 4 2 3}$ & 8.596 & 0.148 \\
& 8 & $\mathbf{3 . 9 2 4}$ & 0.148 & 0.345 & $\mathbf{3 . 3 2 9}$ & 8.979 & 0.149 \\
\hline wrt & 12 & $\mathbf{7 . 5 9 3}$ & 0.168 & 0.683 & 0.101 & 0.174 & 0.141 \\
& 1 & $\mathbf{9 . 2 5 3}$ & 5.047 & 1.313 & 0.157 & 9.296 & 0.149 \\
& 4 & $\mathbf{9 . 3 1 4}$ & 5.366 & 1.488 & 0.158 & 9.346 & 0.150 \\
& $\mathbf{9 . 3 2 3}$ & 5.386 & 1.489 & 0.159 & 9.344 & 0.150 \\
\hline
\end{tabular}

Figure 2. Forecast Error Variance Decomposition for Sectors Innovations

Note: This table shows the relative contribution of innovations in exchange rate (ext), interest rate (int), domestic credit (psc), asset price (asp), consumer price index (cpi) to variations in the forecast error for aggregate output (gdp) and each sector agriculture (agric), building and construction (bcn), manufacturing (man), mining (min), service (ser) and wholesale and retail sector (wrt). 